\title{
Produce and Fish Sampling Program of Los Alamos National Laboratory's Environmental Surveillance Group
}

John G. Salazar

\section{DISCLAIMER}

\footnotetext{
This report was prepared as an account of work sponsored

Government. Neither the United States Government nor any agencycy of the United States bility for the makes any warranty, express or implied or any agency thereof, nor any of their process disclosed, ory, completeness, or usefulness of any infes any legal liability or responsience herein to any represents that its use would not infringe privan, apparatus, product, or ence herein to any specific commercial product, process, or ge privately owned rights. Refer-
} 


\title{
PRODUCE AND FISH SAMPLING PROGRAM OF LOS ALAMOS NATIONAL LABORATORY'S ENVIRONMENTAL SURVEILLANCE GROUP
}

\author{
by
}

John G. Salazar

\begin{abstract}
This report describes produce and fish sampling procedures of the Environmental Surveillance Group at the Los Alamos National Laboratory. The program monitors foodstuffs and fish for possible radioactive contamination from Laboratory operations. Data gathered in this program on radionuclide concentrations help to estimate radiation doses to Laboratory personnel and the public.
\end{abstract}

\section{INTRODUCTION}

As part of the routine environmental surveillance program at Los Alamos National Laboratory, radiation doses from ingestion of produce and fish are estimated. The sampling of produce and fish also helps to determine background levels of potential environmental contaminants and to detect any above-background concentrations caused by Laboratory activities.

\section{PRODUCE AND FISH SAMPLING PROGRAMS}

\section{A. Sampling Program Design}

1. Fruif, Vegetable, and Fish Samples. Fruit, vegetable, and fish samples are collected to monitor possible radioactive contamination from Laboratory operations. Produce samples are collected during the fall harvest in the Los Alamos area and above and below points where intermittent streams that cross the Laboratory join the Rio Grande. Fish samples are collected during the spring, summer, and fall at Cochiti, El Vado, Heron, and Abiquiu Reservoirs.
2. Sampling Locations. Produce samples are categorized in three groups (background, offsite, and onsite). Background samples are collected from various farmers in the Española vicinity (Fig. 1). The Rio Grande and Rio Chama are the main sources of irrigation for this area. These locations are suitable for background samples because they are upstream from the Laboratory and not affected by Laboratory operations. Offsite locations are in the communities of Cochiti, White Rock, Pajarito Acres, and Los Alamos (Fig. 1). Cochiti is dependent on the Rio Grande for irrigation, whereas the others use water from deep wells in the Los Alamos Community water system. Onsite locations are all within the Laboratory's boundaries. Produce harvested from onsite locations is all fruit and its water source is from precipitation.

There are two groups of fish samples: background and offsite. Abiquiu, El Vado, and Heron Reservoirs are used as background sampling locations. They are located on the Rio Chama/Willow Creek drainage and are far enough upstream from the Laboratory that airborne emissions do not affect them (Fig. 1).

The offsite location is Cochiti, which is on the Rio Grande downstream frcia the Laboratory. There are no 


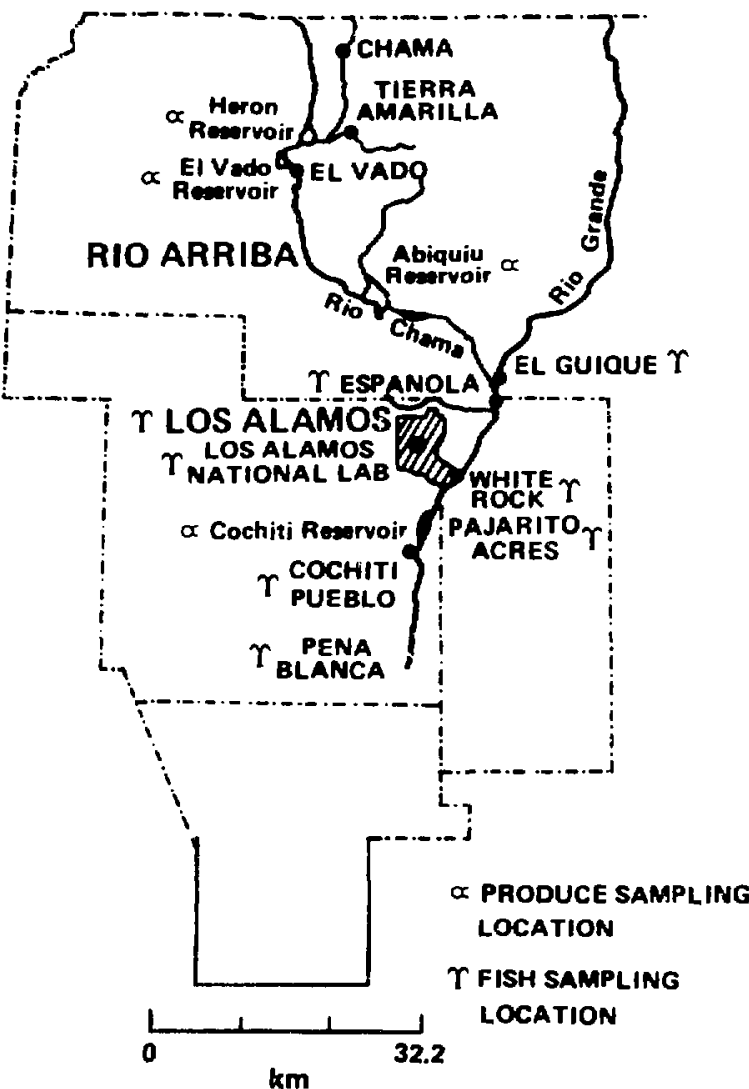

Fig. I. Northern Nen' Mexico region.

onsite sampling locations. because there are no bodies of water that are large enough for fish.

3. Sampling Frequency and Type. Produce and fish samples are collected once a year. Harvest for produce begins in early August and extends through September. Produce collected are garden-variety squash, cucumbers, chile, corn, carrots, melons, tomatoes, peaches, apricots and apples (Fig. 2).

Fish samples are collected between May and September. Fish types include trout, salmon, bass, walleye, catfish, suckers, and cäp (Fig. 3).

4. Sampling Methods and Sample Preparation. During the harvest, produce is bought directly from local farms (Fig. 4). Maps are drawn to show sampling locations within the gardens. This documentation is essential if above-background concentrations of radioactivity are found. The following steps are used for produce samples.

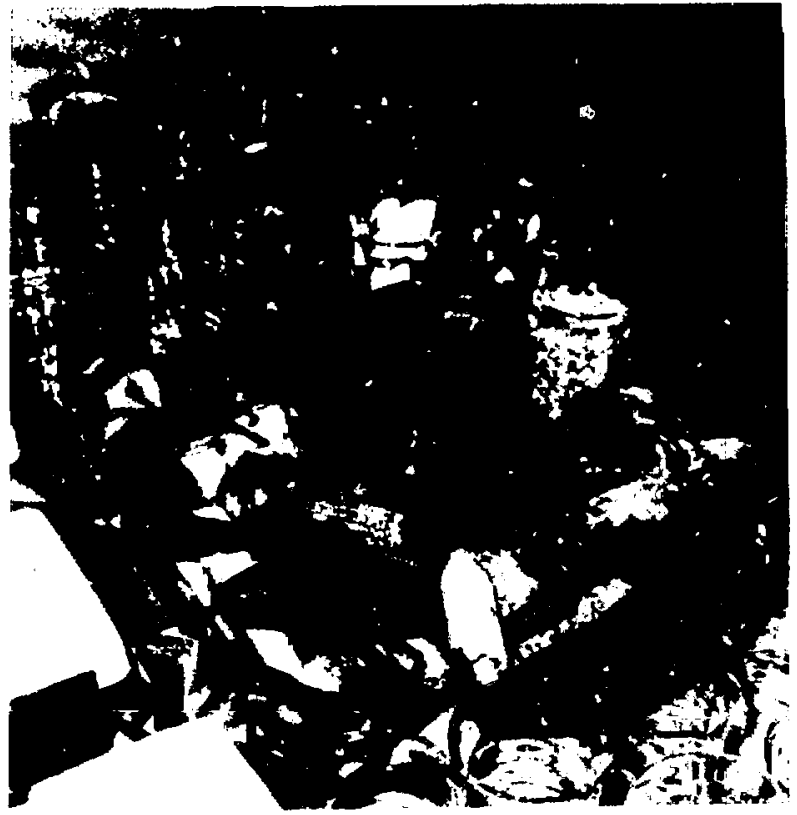

Fig. 2. Fruits and garden-variety' vegetables are collected.

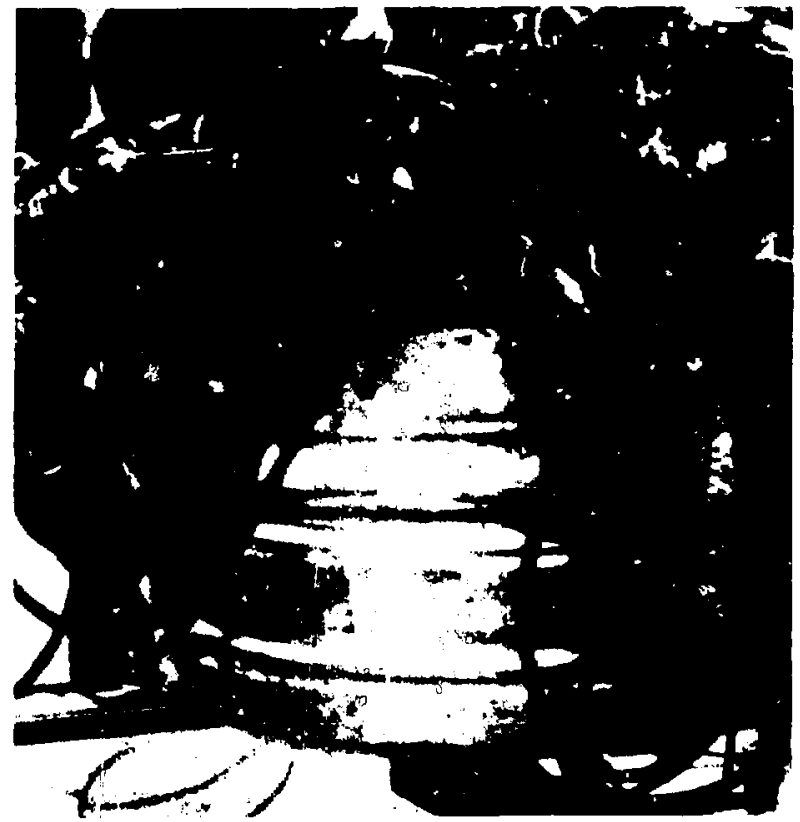

Fig. 3. Ail types of fish caught are used in the fish sampling program. 


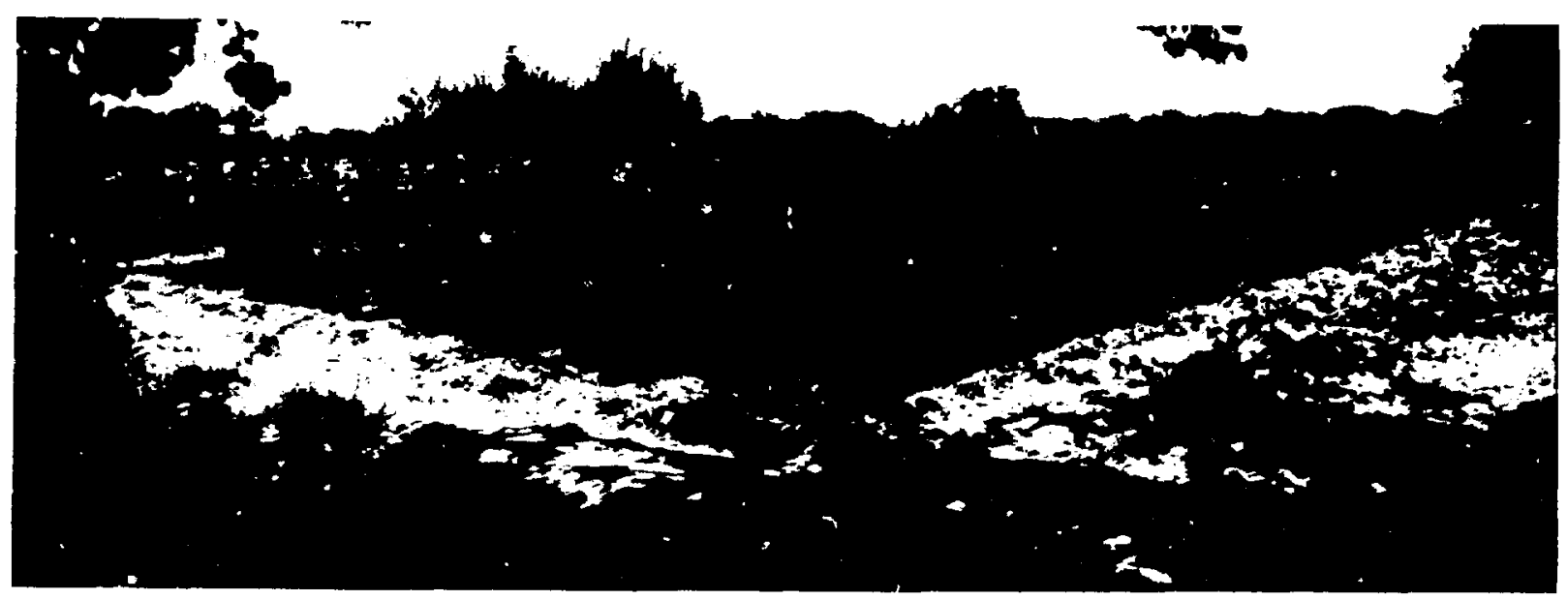

Fig. 4. Fruits and vegetables are purchased from area farmers.
a. Samples are placed in plastic bags and labeled.
b. In the laboratory, produce samples are washed and towel dried, as they would be before being eaten.
c. Samples are diced and put into a tared $1000 \mathrm{ml}$ beaker.
d. Wet weights are determined.
e. Five milliliters of moisture is distilled from produce samples for tritium analysis.
f. Samples are oven dried at $100^{\circ} \mathrm{C}(\sim 48 \mathrm{~h})$.
g. Oven-dried weights are determined.
h. Samples are ash dried at $400^{\circ} \mathrm{C}(\sim 72$ to $96 \mathrm{~h})$.
i. Ash weights are determined.
j. Samples are submitted for analysis.

There are two groups of fish samples: higher-level feeder (game fish) and bottom-level feeder (nongame fish). The fish are dissected and the entrails and muscle tissues kept in separate beakers (Fig. 5). Steps c, d, f, g, h, $\mathrm{i}$, and $\mathrm{j}$ from the produce sampling apply.

5. Radionuclides Sampled. Both produce and fish samples are analyzed for ${ }^{238,239} \mathrm{Pu}, \mathrm{U},{ }^{137} \mathrm{Cs}$, and ${ }^{90} \mathrm{Sr}$ concentrations. Only produce samples are analyzed for tritiated water (HTO or $\mathrm{T}_{2} \mathrm{O}$ ) (Fig. 6). These radionuclides are most likely to be released into the environment by Laboratory activities.

\section{B. Sampling Equipment}

The Environmental Surveillance Group (HSE-8) has been granted a fish collecting permit from the New Mexico Department of Game and Fish. This permit is

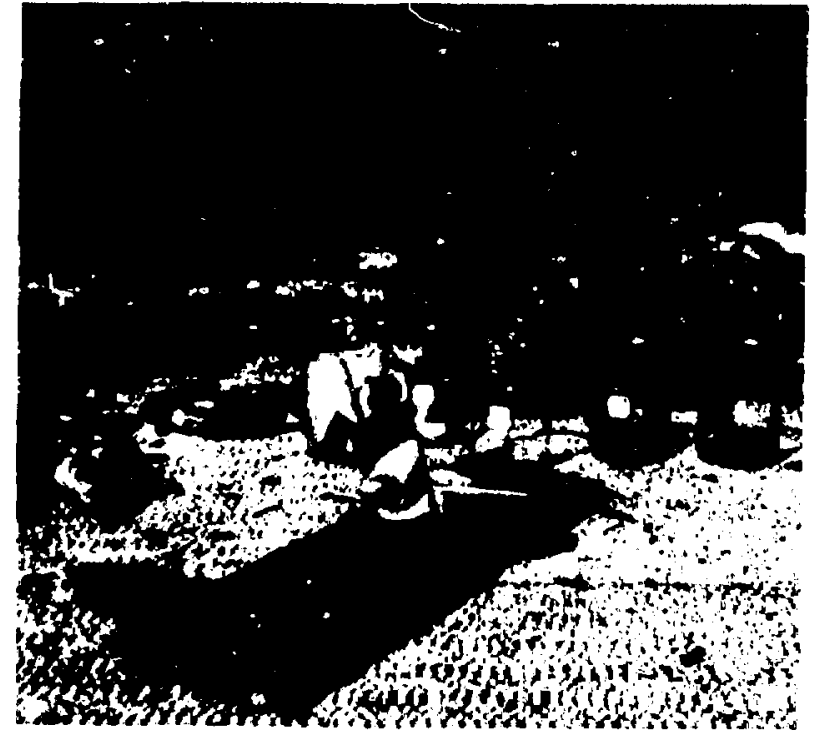

Fig. 5. Dissected fish are placed into beakers.

issued yearly and must be in possession of the permittee during fish collecting trips.

HSE- 8 currently uses a 5 meter $(17 \mathrm{ft})$, modified V-hull boat with an $80 \mathrm{hp}$ motor for fish sampling. Gill nets are used to catch the fish [(1-1/2 mesh, $30 \times 1.3$ meter $(100 \mathrm{ft}$ by $6 \mathrm{ft}$ )] (Fig. 7). Tubs, meat cleavers, knives, and woodcutting blocks are used in the produce and fish sampling procedures. 


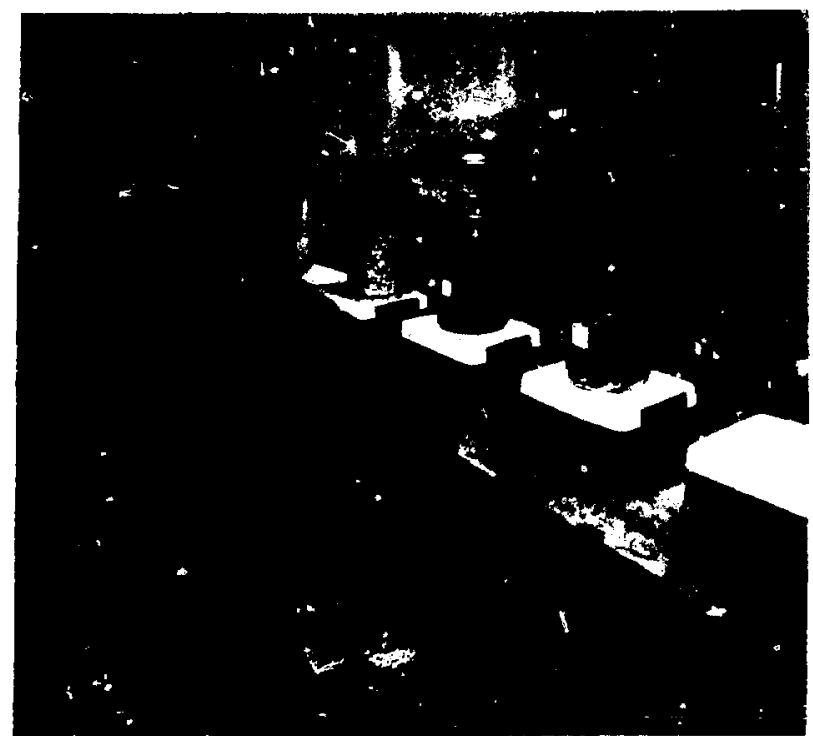

Fig. 6. Vegetable samples are heated for tritium analysis.

\section{Analytical Methods ${ }^{1}$}

1. Tritium. Only produce samples are analyzed for tritium. Water $\left(\mathrm{H}_{2} \mathrm{O}, \mathrm{HTO}, \mathrm{T}_{2} \mathrm{O}\right)$ is distilled $(4 \mathrm{~h}$ at $120^{\circ} \mathrm{C}$ ) frorn produce samples and collected. A $5 \mathrm{ml}$ aliquot of the collected water is then counted by liquid scintillation. Fifteen milliliters of scintillation liquid is added and the solution vigorously shaken. The sample is counted in a liquid scintillation counter for $50 \mathrm{~min}$ or 10000 counts, whichever comes first. Quality control standards and blanks are counted in conjunction with each set of samples.

2. Plutonium 238 and 239. Produce and fish samples are burned to ash in high-temperature ovens and then leached with $\mathrm{HF}-\mathrm{HNO}_{3}$. Ail samples are spiked with standardized ${ }^{242} \mathrm{Pu}$ and ${ }^{243} \mathrm{Am}$ during dissolution to serve as a chemical recovery tracer.

Dissolved samples are thoroughly digested in $7.2 \mathrm{M}$ $\mathrm{HNO}_{3}$, and $1 \mathrm{M} \mathrm{NaNO}$ is added to ensure that plutonium is in the tetravalent state. The solution is passed through a preconditioned anion-exchange column. The initial eluate and the first $20 \mathrm{~m} \ell$ of a $7.2 \mathrm{M} \mathrm{HNO}_{3}$ wash is saved for ${ }^{241} \mathrm{Am}$ analysis. The column is then washed with $7.2 \mathrm{M} \mathrm{HNO}_{3}$ and $8 \mathrm{M} \mathrm{HCl}$. Plutonium is eluted with a freshly prepared solution of $1 \mathrm{~g} / \ell \mathrm{NHI}$ in $1 \mathrm{M} \mathrm{HCl}$. The

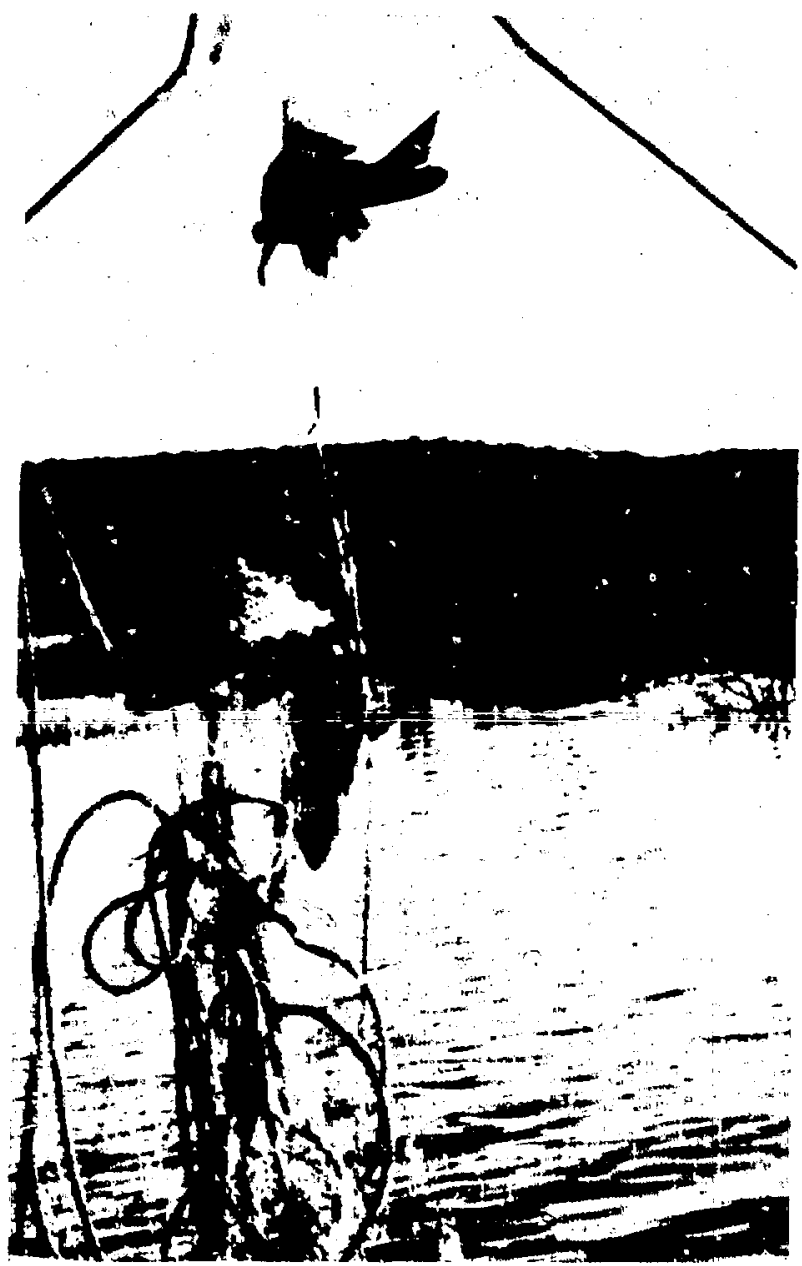

Fig. 7. Gill nets are used to critch fish.

eluate is appropriately conditioned, and plutonium is electrodeposited from a $4 \%$ solution of $\left(\mathrm{NH}_{4}\right)_{2} \mathrm{C}_{2} \mathrm{O}_{4}$. The plated plutonium is counted on an alpha spectrometer. Values reported for ${ }^{239} \mathrm{Pu}$ are the sum of ${ }^{239} \mathrm{Pu}$ and ${ }^{240} \mathrm{Pu}$, because both have identical alpha energies.

3. Uranium. Samples are analyzed for total uranium by delayed neutron activation. The samples are irradiated in a thermal neutron port at Los Alamos National Laboratory's Omega West Reactor and pneumatically transferred to a neutron counter where the delayed neutrons produced by the fission of ${ }^{235} \mathrm{U}$ are measured. Total uranium is calculated assuming the natural ${ }^{233} \mathrm{U} /{ }^{238} \mathrm{U}$ ratio of 0.0072 . 
4. Cesium 137. One hundred grams of ash are weighed into $500 \mathrm{ml}$ polyethylene bottles and filled with $7.2 \mathrm{ml} \mathrm{HNO}_{3}$. The amount of ${ }^{137} \mathrm{Cs}$ is determined by counting on a $\mathrm{Ge}(\mathrm{Li})$ detector coupled to a multichannel analyzer. The activity is calculated by direct comparison with standards prepared in the same geometrical corifiguration as the samples. Gross gamma activity is measured by counting in an $\mathrm{NaI}(\mathrm{T})$ well counter, which accommodates the $500 \mathrm{ml}$ bottles. A single-channel analyzer adjusted to register gamma radiation between 0 and $2 \mathrm{MeV}$ is interfaced to the detector. Gross gamma determinations are reported as net counts per unit time and unit weight.

5. Strontium 90. Sample preparation and dissolutions are similar to those described in the section on plutonium. After dissolution, the residue is dissolved in $\mathrm{HCl}$, the $\mathrm{pH}$ is adjusted to 2, and yttrium is separated from strontium by extraction into $20 \%$ HDEHP in toluene. The isolated ${ }^{90} \mathrm{Sr}$ is left urdisturbed for 2 weeks to allow the daughter ${ }^{90} \mathrm{Y}$ to attain radioactive equilibrium. After that period, inactive yttrium carrier is added and ${ }^{90} \mathrm{Y}$ is again extracted from ${ }^{90} \mathrm{Sr}$ by solvent extraction into $5 \%$ HDEHP in toluene. Yttrium is back extracted into $3 \mathrm{M} \mathrm{HNO}_{3}$ and precipitated as the hydroxide. Yttrium hydroxide is redissolved and the oxalate is precipitated. This precipitate is oven fired to the oxide and then filtered and weighed to determine the chemical yield. Yttrium oxide precipitate is counted on a gas proportional ccunter to measure the activity. Samples are recounted after 3 days to verify the separation of ${ }^{90} \mathrm{Y}$ from other beta-emitting nuclides.

\section{Data Analysis}

1. Statistical Treatment of Data. There are three groups of produce samples: background (Rio Chama and upper Rio Grande at Española), offsite (Cochiti, Los Alamos, White Rock, and Pajarito Acres), and onsite (any fruit bearing trees on Laboratory property) (Table I). The two groups (game and nongame fish) of fish samples are subcategorized into bottom-level feeders and higher-level feeders (Table II). ${ }^{2}$

2. Variance, $t$ Test, Degrees of Freedom. ${ }^{3}$ The variances are calculated by using the following equation:

$$
S^{2}=\frac{\sum_{i=1}^{N}\left(C_{i}-\bar{C}\right)^{2}}{n-1}
$$

where

$C_{i}=$ radionuclide concentration in sample $i$,

$\overline{\mathrm{C}}=$ mean radionuclide concentration of the $\mathrm{n}$ of samples,

$\mathrm{n}=$ number of samples, and

$S^{2}=$ variance of radionuclide concentrations in a group.

A Students' $t$ test ${ }^{3}$ is used to determine if there are any statistically significant differences among group means:

$$
\mathrm{t}=\frac{\overline{\mathrm{C}}_{1}-\overline{\mathrm{C}}_{2}}{\sqrt{\frac{\mathrm{S}_{1}^{2}}{\mathrm{n}_{1}}+\frac{\mathrm{S}_{2}^{2}}{n_{2}}}},
$$

where

$\overline{\mathrm{C}}_{1}=$ mean radionuclide concentration of group 1 ,

$\overline{\mathbf{C}}_{2}=$ mean radionuclide concentration of group 2 ,

$\mathrm{S}_{2}^{2}=$ variance of group 1 ,

$S_{2}^{2}=$ variance of group 2 ,

$\mathrm{n}_{1}=$ number of samples in group 1 , and

$n_{2}=$ number of samples in group 2 .

The degrees of freedom (df) are calculated as follows.

$$
d f=\frac{\left(\frac{S_{1}^{2}}{n_{1}}+\frac{S_{2}^{2}}{n_{2}}\right)^{2}}{\frac{\left(\frac{S_{1}^{2}}{n_{1}}\right)^{2}}{n_{1}+1}+\frac{\left(\frac{S_{2}^{2}}{n_{2}}\right)^{2}}{n_{2}+1}}-2
$$

The two-sided critical region at level of significance $\alpha=$ 0.05 (that is, $5 \%$ ) is calculated as shown.

$\mathrm{t} \leqq \mathrm{t}_{\mathrm{\alpha} / 2}, \mathrm{t} \geqq \mathrm{t}_{1-(\alpha / 2)}$,

where

$\mathbf{t}=$ calculated Student's $\mathbf{t}$ percentile, and

$t_{\alpha / 2}, t_{1-(\alpha / 2)}=$ percentiles of Student's $t$ distribution at $\alpha / 2$ level of significance (two-tailed test).

3. Data Handling. Currently, analytical results from produce and fish samples are stored in the Environmental Surveillance Group's minicomputer with information such as sample number, sample type, location, weights, 
TABLE I

RADIONUCLIDE CONTENT OF FRUITS AND VEGETABLES COLLECTED DURING 1983

\begin{tabular}{|c|c|c|c|c|c|c|c|c|}
\hline \multirow{3}{*}{$\begin{array}{l}\text { Locution: } \\
\text { Water Source: }\end{array}$} & \multirow{2}{*}{\multicolumn{2}{|c|}{ Eeckyround }} & \multicolumn{3}{|c|}{ Unsite } & \multirow{2}{*}{\multicolumn{3}{|c|}{ Onsite }} \\
\hline & & & \multirow{2}{*}{$\begin{array}{c}\text { Cuchis } \\
\text { Riw Grande }\end{array}$} & \multirow{2}{*}{$\begin{array}{c}\text { Los Alenius } \\
\text { Comonumity System }\end{array}$} & \multirow{2}{*}{$\begin{array}{c}\text { White Rickv } \\
\text { Pajarilu Acses } \\
\text { Cummunity Systern }\end{array}$} & & & \\
\hline & Rio Chama & Ro Grende & & & & TA 3 & TA.21 & TA.39 \\
\hline \multicolumn{9}{|l|}{ Redionuclide: } \\
\hline \multirow{2}{*}{\multicolumn{9}{|c|}{$\begin{array}{l}{ }^{23} \mathrm{Pu} \text { (pCi/ dry weight } \\
\text { No. of Samples }\end{array}$}} \\
\hline & 5 & 10 & 15 & 3 & 10 & 3 & 2 & 1 \\
\hline Maxumum" & $0.00075 \neq 000050$ & $0.00043,0.00043$ & $000024,0.0014$ & $000031+0.00027$ & $0.000043+0.00067$ & $0.00071+0.00024$ & $0.00044 \pm 0.000881$ & \\
\hline Minimuma" & $-0.00012 \times 0.04035$ & $-0.00030+0.00030$ & $0.00044,0.000044$ & $000006 \div 0.00014$ & $0.00011+0.00004$ & $0.00013,0.00020$ & $0.00010+0.00015$ & \\
\hline$x \geq 3$ & $0.00020 \div 0.00033$ & $0.00005+0.00022$ & $0.00027+000071$ & $0.00009+0.00019$ & $0.00029 \div 0.00028$ & $0.00032 \pm 0.00033$ & $0.00030+0.00028$ & $0.00020 \pm 0.00039$ \\
\hline \multicolumn{9}{|l|}{$234.240 \mathrm{Pu}\{\mathrm{pC} / \mathrm{l}$ dry weight\} } \\
\hline No. of Sumples & 5 & 10 & 15 & 3 & 10 & 3 & 2 & 1 \\
\hline Manomum" & $0.00033 \div 0.00010$ & $00012,0.00042$ & 0.0033 \& 000100 & $0.00027 \div 0.00011$ & $0.0033 .3 \pm 0.0010$ & $0.00051+0.00020$ & $0.00049+0.00044$ & $\cdots$ \\
\hline Minumuman & $-0.00035+0.00059$ & $-0.00083+0.00050$ & $0.00008 \div 0.00010$ & $-0.00031+0.00016$ & $0(x) 14+0(0 \times 129$ & $0.00020+0.00013$ & $0.00005+0.00010$ & $\ldots$ \\
\hline i 15 & $0.90009+9.00026$ & $0.00016 \div 0.00053$ & $0.00044+0.00081$ & $0.00005+0.00031$ & $000069,0.00096$ & $0.00037 \pm 0.00016$ & $0.00027 \pm 0.00031$ & $-0.00020 \pm 0.00039$ \\
\hline \multicolumn{9}{|l|}{ Lressum (ue/g dry weizht) } \\
\hline No. of Samples & 5 & 9 & 15 & 3 & 10 & 3 & 2 & I \\
\hline Maxtmum" & $0.022,0.005$ & $0.012 \div 0.0033$ & $0.024 \pm 0.0048$ & $0011+0.0021$ & $015 \div 0.027$ & $0.059,0.0083$ & $0.042 \pm 0.006$ & $\ldots$ \\
\hline Minimum & $0.0005 \div 0.0006$ & $0.0000 \div 0.0009$ & $000083 \div 0.00058$ & $00010 \div 00008$ & $0.00008 \div 0.00072$ & $0.0088 \div 0.0030$ & $0.0045 \pm 0.0024$ & $\ldots$ \\
\hline$i: 5$ & $0.0084 \div 0.0085$ & $0.0057 \pm 0.0048$ & $0.0076 \pm 0.0068$ & $0.0047+0.0053$ & $0.0018 \div 0.047$ & $0.040 \pm 0.028$ & $0.023 \div 0.026$ & $0.0045 \pm 0.0018$ \\
\hline \multicolumn{9}{|l|}{${ }^{131} \mathrm{Cs}_{\text {(pCi//8 dry weighu) }}$} \\
\hline Ne. of Samples & 5 & 10 & 15 & 3 & 10 & 3 & 2 & 1 \\
\hline Manssum" & $0.97+1.46$ & $1.83 \div 0.42$ & $124+i 21$ & $0.46 \pm 0.63$ & $2.07,0.90$ & $0.41 \pm 0.19$ & $0.37 \pm 0.31$ & $\cdots$ \\
\hline Minimuma & $-139 \div 1.88$ & $-1.11 \div 065$ & $107 \pm 1.02$ & $-0.63 \pm 1.01$ & $-116: 0.32$ & $0.18 \div 0.13$ & $0.18 \pm 0.23$ & $\ldots$ \\
\hline$i \pm s$ & $-0.082+0.91$ & $0.067 \pm 0.72$ & $-0.053+0.60$ & $0.05 \pm 0.59$ & $0.34 \div 1.06$ & $0.17 \pm 0.31$ & $0.28 \pm 0.13$ & $-0.44 \pm 0.41$ \\
\hline \multicolumn{9}{|l|}{$\mathrm{wS}_{\mathrm{St}}\left(\mathrm{pC} \mathrm{v}_{\mathrm{g}}\right.$ dry wersh) } \\
\hline No. of Samples & 5 & 10 & 11 & 1 & 8 & 2 & 1 & $\mathbf{I}$ \\
\hline Meximum" & $0.052 \pm 0.0071$ & $0.10 \pm 0.011$ & $024+0020$ & & $0.076 \pm 00017$ & $0.070 \times 0.0931$ & & \\
\hline Mın:mum" & $-0.0016 \pm 0.0048$ & $00012 \div 0.0012$ & $0.0063,0.0013$ & & $0.0022 \div 0.0015$ & $0.011 \div 0.0035$ & . & $\cdots$ \\
\hline i 15 & $0.025 \div 0.025$ & $0.029 \div 0.034$ & $0.056 \div 0.081$ & O(x)Hy $=0.0089$ & $0.027 \div 0.023$ & $0.040 \div 0.042$ & $0.0031 \div 0.0031$ & $0.028 \div 0.0073$ \\
\hline
\end{tabular}


TABLE II

RADIONUCLIDE CONTENT OF FISH COLLECTED DURING 1983

Abiquiv. El Vado. and Heron Reservuirs

Botom Ferders

Higher Lever

Higher level

Andonucitide:

23mpu (pCi/s dsy weight)

No. of Samples

Maximumi

Minsmum

10
0.00004 0000011

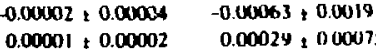

8
0.00006 + 0.00003
$0.000006+000005$
$0.00000+0.00005$

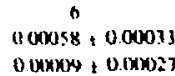

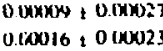

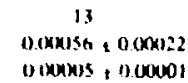

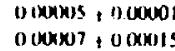

10
$000344+0.0038$
$-0.00024+0.000738$
$0.000085+0.00017$

$$
6
$$

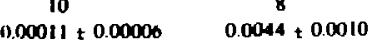
$0.00009+0.00010$ $0.00003 \div 0.00006$

$0.00011+0.00011$

0.000006t t 0.000005

occour2 t onows

$000002,0.00006$

$0.001+0.0 \times 03$

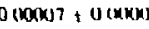

$1.000041,0.00040$

13
$0.0607 x+000022$
$0(00118 \div 000012$
$0(00011+000029$

10

$0.0059+0.0011$

$0.000158+0.00068$

$0 .(x) 20+0.0019$

\section{0}

$0.0501+0.0051$ $0.0079+0.0010$ $0.020 \div 0.014$

9

$0.33+0.03$

$0.058 \div 0.006$

8

$0.0061+0.0010$

$0.0000+0.0019$

6

0044,0008

$0.0016+0.0007$

$0.0018+0.0024$

$0028 \div 0.034$

${ }^{137} \mathrm{Cs}$ (pCi/g dry weight)

No of Samples

Minimum

i $\pm s$

10
$0.39+0.28$
$-1.4+1.2$
$-0.076 \pm 0.49$

$0.45+0.14$

$0.45+0.14$
$.1 .4+25$

$.1 .4+25$
$0.0002+0.57$

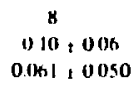

$0.0 \% 1+0050$
0.038 \& 0055

5

$073+0.28$

$1.3+05$

$0.23 \div 076$

10
$023 \div 0.009$
$0.069 \div 0004$ $0.069 \div 0004$
$014 \div 0.050$

$\stackrel{8}{0.082}+0.006$

$0.082+0.006$
$0.01244+0.0046$

$0.027+0.024$
4
0056

$00011+0007$

$0.023 \div 0026$
$0056+0.057$

$0(3) \div 4+00001$

$0.027 \div 0014$

13

017,010

(1) $14+(11)$

$00163: 011$

12

$011 \div 0005$
$0035 \div 0003$

$0107 \mathrm{~b}+00125$
$0.043+03140$
10

$139 \pm 0.14$

$0.075 \div 0.0075$

$0.44,0.38$

10
$058 \div 0.66$

$058+0.66$
$016+0.15$

$0.20+0.24$

10
$03 n+002$

$0.0018+0.0018$

$0.0018+00018$
Cochini Reservoir

Higher Leves $\quad \begin{gathered}\text { Hieher Level } \\ \text { (gut }\end{gathered}$

$x+5$
$0.00006+0.00000$

$0.00014 \div 0.0000$

$.0 .00003+0.00008$

8

$0.00021+0.00000$

$-0.00011+0.00000$

$0.00006+0.00009$

8

$0.021 \div 0.005$

$0.0053+0.0018$

$0.0088+0.0051$

8

$0.15 \div 0.07$

$-0.58 \pm 0.54$

$0.063+0.25$

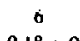

$0.18+0.007$

$0.049+0.002$

$0.093 \pm 0.046$ $s$

$0.00028+0.0000$

$0.00004+0.00000$

$0.00013 \div 0.00012$

5

$0.0023 \div 0.0020$ $0.0002+0.00005$

-Samples consisted of fish less digestive system Igu|

Samples consisted of got only

counting uncertanty. 
and analytical results. Information can be extracted from the data bases to generate summary reports (Tables I and II).

\section{ACKNOWLEDGMENTS}

Thanks to the following people for their technical input, editorial reviews, typing, and phototypesecting: Tom Gunderson, Richard Romero, Tom Buhl, Daniei Talley, Dan Perrin, Richard Peters, Colleen Burns, and Kathy Derouin.

\section{REFERENCES}

1. "Environmental Surveillance at Los Alamos During 1980," Los Alamos National Laboratory report LA-8810-ENV (April 1981).

2. "Environmental Surveillance at Los Alamos During 1983," Los Alamos National Laboratory report LA-10100-ENV (April 1984).

3. M. G. Natrella, Experimental Statistics, National Bureau of Standards Handbook 91 (August 1963). 